\title{
Hubungan Riwayat Pemberian Makanan Pendamping ASI (MP-ASI) dengan Persepsi Perilaku Picky Eater pada Anak Usia 12-36 Bulan (Studi di Wilayah Kerja Sidotopo Surabaya)
}

\section{Correlation Between History of Complementary Feeding and Perception of Picky Eater Behavior among Children Age 12-36 Month (Study in Sidotopo Health Center Working Area, Surabaya City)}

\author{
Arian Susanti Dewi Cahyani*1
}

\begin{abstract}
ABSTRAK
Latar Belakang : Anak usia pra-sekolah sering mengalami perilaku picky eater. Persepsi perilaku picky eater digambarkan bahwa anak cenderung memiliki preferensi makanan yang kuat, konsumsi makanan yang kurang beragam, membatasi asupan beberapa kelompok makanan tertentu dan tidak mau mencoba makanan baru. Salah satu faktor yang melatarbelakangi picky eater adalah riwayat pemberian Makanan Pendamping ASI (MP-ASI).

Tujuan : Tujuan dari penelitian ini untuk menganalisis hubungan riwayat pemberian MP-ASI dengan persepsi perilaku picky eater pada anak usia 12-36 bulan.

Metode : Jenis penelitian ini merupakan observasional analitik menggunakan desain penelitian cross-sectional. Penelitian ini dilaksanakan di wilayah kerja Puskesmas Sidotopo Surabaya. Sampel penelitian sebesar 78 anak berusia 12-36 bulan. Kriteria inklusi yang ditetapkan adalah anak tidak memiliki riwayat alergi makanan. Pengambilan sampel dengan menggunakan teknik simple random sampling. Pengumpulan data dengan wawancara menggunakan kuesioner meliputi karakteristik anak dan ibu, riwayat pemberian makanan pendamping ASI (MP-ASI) dan persepsi perilaku picky eater. Data dianalisis dengan menggunakan uji statistik Chi-Square.

Hasil : Hasil penelitian menunjukkan bahwa riwayat pemberian MP-ASI pada anak sebagian besar tidak sesuai yaitu $66,7 \%$ dan prevalensi persepsi perilaku picky eater pada anak sebesar $48,7 \%$. Terdapat hubungan antara riwayat pemberian MPASI dengan persepsi perilaku picky eater $(p<0,001)$.

Kesimpulan : Terdapat hubungan antara riwayat pemberian MP-ASI dengan persepsi perilaku picky eater pada anak usia 12-36 bulan. Anak dengan riwayat pemberian MP-ASI yang tidak sesuai cenderung memiliki perilaku picky eater.
\end{abstract}

Kata kunci: Makanan Pendamping ASI (MP-ASI), persepsi perilaku picky eater, anak usia pra-sekolah

\section{ABSTRACT}

Background : Pre-school age children often have picky eater behavior. Perception of picky eater usually describes as the strong preference of children for food, inadequate of dietary diversity, restrain of certain food groups and won't try new food. One of factors that causes this behavior is history of complementary feeding.

Objectives: This study purposes was to analyze correlation between history of complementary feeding and perception of picky eater behavior among children age 12-36 month old

Methods: This study was analytic observasional study with cross-sectional design. The research was conducted in Sidotopo Health Center Surabaya City. There were 75 children age 12-36 month old. The inclusion criteria are children who have no history of food allergies. Sample was chosen by simple random sampling. Data collected by interview using questionnaires included characteristics of children and mothers, history of complementary feeding and perceptions of picky eater behavior. The data was analyzed by chi-square test.

Results: The result show that inappropriate history of complementary feeding in children was $66.7 \%$ and prevalensi perception of picky eater behavior in children was $48.7 \%$. There was significant correlation between history of complementary feeding and perception of picky eater behavior $(p<0.001)$.

Conclusions : There was a relationship between history of complementary feeding and perceptions of picky eater behavior among children age 12-36 month. Children with inappropriate history of complementary feeding tend to have picky eater behavior.

Keywords: history of complementary feeding, perception of picky eater behavior, pre-school age children 


\author{
*Koresponden: \\ ariansdc@gmail.com \\ 1Progam Studi S-1 Gizi Fakultas Kesehatan Masyarakat, Universitas Airlangga, Kampus C Mulyorejo 66115, \\ Surabaya, Jawa Timur, Indonesia
}

\section{PENDAHULUAN}

Picky eater adalah suatu perilaku pilih-pilih makanan pada anak-anak biasanya digambarkan dengan anak cenderung memiliki preferensi makanan yang kuat, konsumsi makanan yang kurang beragam, membatasi asupan beberapa kelompok makanan tertentu dan tidak mau mencoba makanan baru. Picky eater makan cenderung sering terjadi pada anak usia pra-sekolah. Penelitian yang dilakukan di China tahun 2017 prevalensi picky eater lebih tinggi pada anak usia 24-35 bulan (36\%) dibandingkan dengan anak usia $6-11$ bulan $(12 \%)^{1}$. Di Indonesia khususnya di daerah Gamping Kidul Ambarketawang Gamping Sleman Yogyakarta tahun 2018 pada anak usia $12-36$ bulan sebesar $25,81 \%$ anak mengalami picky eater ${ }^{2}$. Studi yang dilakukan di Kabupaten Jember tahun 2016 dilakukan penelitian pada anak usia 12-36 bulan didapatkan 46,2\% mengalami picky eater ${ }^{3}$. Berdasarkan beberapa penelitian diatas menunjukan bahwa prevalensi picky eater pada anak usia pra-sekolah tergolong masih tinggi.

Picky eater dapat dipengaruhi oleh beberapa faktor antara lain cara pemberian makan yang kurang tepat, frekuensi makan, waktu makan, riwayat ASI eksklusif, riwayat pemberian MP-ASI, interaksi antara anak dan ibu yang kurang baik, perilaku makan orang tua, sosial budaya, dan penyakit yang diderita anak ${ }^{4}$. Pemberian MP-ASI yang kurang tepat dapat mempengaruhi perilaku picky eater pada anak. Pemberian MP-ASI yang dilakukan terlalu dini akan menyebabkan timbulnya perilaku takut dalam mencoba makanan baru (neofobia) dengan risiko hingga 2,5 kali lipat. Selain dapat menyebabkan perilaku neofobia pada makanan, MP-ASI yang dikenalkan pada usia sebelum 6 bulan dapat menyebabkan kurang bervariasinya makanan karena terbatasnya asupan makan ${ }^{5}$. Dalam praktik pemberian makanan kepada bayi perlu diperhatikan ketepatan jenis, jumlah, frekuensi dan waktu pemberian ${ }^{6}$. Pengalaman makanan yang dibentuk dari segi rasa dan tekstur akan menentukan penerimaan makanan pada anak ${ }^{7}$.

Hasil studi pendahuluan menunjukkan bahwa persepsi perilaku picky eater di wilayah kerja Puskesmas Sidotopo Surabaya, sebanyak $45 \%$ anak mengalami perilaku picky eater. Salah satu faktor yang dapat mempengaruhi perilaku picky eater yakni pemberian MP-ASI. Prevalensi ASI Eksklusif di Puskesmas Sidotopo ASI eksklusif pada tahun 2018 yaitu 68,2\%. Hal tersebut menandakan hampir separuh pemberian MP-ASI dilakukan lebih dini. Sehingga peneliti ingin melihat hubungan riwayat pemberian MP-ASI dengan persepsi perilaku picky eater pada anak usia 12 - 36 bulan di wilayah kerja Puskesmas Sidotopo Surabaya.

\section{METODE}

Jenis penelitian ini adalah observasional analitik dengan desain penelitian cross-sectional. Penelitian dilaksanakan di wilayah kerja Puskesmas Sidotopo Surabaya bulan April - Juni 2019. Penelitian ini memiliki kriteria inklusi yang ditetapkan yaitu anak tidak memiliki riwayat alergi makanan. Variabel independen dalam penelitian ini adalah karakteristik anak, riwayat pemberian MP-ASI dan variabel dependen yakni persepsi perilaku picky eater anak usia $12-36$ bulan.

Sampel penelitian ini sebesar 78 anak berusia 1236 bulan di posyandu wilayah kerja Puskesmas Sidotopo yang dihitung menggunakan rumus Lemeshow (1997). Responden dari penelitian ini adalah ibu dari anak tersebut. Pengambilan sampel dilakukan menggunakan teknik simple random sampling yaitu peneliti memberi nomor urut pada setiap populasi dengan cara membuat daftar sehingga masing-masing individu memiliki nomor yang berbeda kemudian dilakukan pengacakan menggunakan aplikasi acak nomor. Teknik pengambilan sampel ini memberikan peluang yang sama pada semua anggota populasi untuk menjadi sampel penelitian.

Pengumpulan data melalui wawancara menggunakan kuesioner meliputi karakteristik anak dan ibu, riwayat pemberian makanan pendamping ASI (MPASI) dan persepsi perilaku picky eater. Lembar kuesioner riwayat pemberian makanan pendamping ASI (MP-ASI) terdiri dari 6 pertanyaan. Penentuan kesesuaian berdasarkan jumlah skor. Jumlah skor maksimal yaitu 15 dan skor minimal yaitu 2. Diklasifikasikan menjadi sesuai jika skor 15 dan tidak sesuai jika skor $<15$. Lembar kuesioner persepsi perilaku picky eater dari kuesioner Goh dan Jacob (2012) yang dimodifikasi. Kuesioner terdiri dari 12 pertanyaan, jawaban setiap pertanyaan menggunakan penilaian dengan skala likert. Penentuan persepsi ibu terhadap perilaku picky eater berdasarkan jumlah skor. Jumlah skor maksimal yaitu 48 dan skor minimal yaitu 12. Diklasifikasikan menjadi bukan perilaku picky eater jika skor <24 dan perilaku picky eater jika skor $\geq 24$.

Analisis data dilakukan dengan menggunakan uji statistik Chi-Square. Penelitian ini telah layak kaji etik dari komisi etik penelitian kesehatan Fakultas Keperawatan Universitas Airlangga Surabaya dengan nomor 1373-KEPK tanggal 26 April 2019.

\section{HASIL DAN PEMBAHASAN}

\section{Karakteristik Anak}

Karakteristik anak salah satunya yaitu usia. Rentang usia anak dalam penelitian ini adalah $12-36$ bulan. Rata-rata anak pada usia 24,36 bulan $\pm 7,27$. Berdasarkan Tabel 2, sebagian besar usia anak pada kelompok usia 12-24 bulan sebanyak 56,4\%. Berdasarkan Tabel 3. sebagian besar anak pada kelompok usia $25-36$ bulan sebesar $64,7 \%$ mengalami perilaku picky eater. Sejalan dengan penelitian Li tahun 2017 di China pada anak usia 24-35 bulan sebesar 36,1\% mengalami perilaku picky eater ${ }^{1}$. Berdasarkan hasil penelitian Kusumawardhani tahun 2013 didapatkan bahwa baik kelompok anak picky eater maupun bukan 
picky eater sebagian besar berusia 24-36 bulan 4 . Anak usia 24-36 bulan dalam pemilihan, penerimaan dan makanan lebih dapat dilihat karena anak sudah lebih mengerti apa yang diinginkan dan disukai. Usia balita merupakan masa anak menjadi selektif terhadap pilihan makanan dan sering melakukan penolakan makan sehingga dapat terjadi penurunan berat badan ${ }^{8}$.

Berdasarkan hasil Tabel 2, Dapat dilihat bahwa sebagian besar anak yang berjenis kelamin laki-laki sebanyak 51,3\%. Berdasarkan Tabel 3. Anak yang berjenis kelamin laki-laki sebagian besar mengalami perilaku picky eater sebesar 52,5\%. Tidak terdapat hubungan antara jenis kelamin dengan persepsi perilaku picky eater $(p=0,493)$. Laki-laki maupun perempuan dapat mengalami perilaku picky eater. Tidak terdapat perbedaan secara signifikan pada anak berjenis kelamin laki-laki maupun perempuan yang mengalami perilaku picky eater ${ }^{9}$.

Tabel 2. Distribusi Karakteristik Anak

\begin{tabular}{lcc}
\hline \multicolumn{1}{c}{ Variabel } & \multicolumn{2}{c}{ Jumlah } \\
\cline { 2 - 3 } & $\mathbf{n}$ & $\%$ \\
\hline Usia & & \\
12-24 bulan & 44 & 56,4 \\
25-36 bulan & 34 & 43,6 \\
Jenis Kelamin & & \\
Laki-laki & 44 & 56,4 \\
Perempuan & 34 & 43,6 \\
\hline Total & 78 & 100,0 \\
\hline
\end{tabular}

Tabel 3. Distribusi Persepsi Perilaku Picky Eater berdasarkan Karakteristik Anak

\begin{tabular}{llcc}
\hline \multicolumn{1}{c}{ Karakteristik Anak } & \multicolumn{2}{c}{ Persepsi Perilaku Picky Eater } & \multirow{2}{*}{ p-value* } \\
\cline { 2 - 3 } & \multicolumn{1}{c}{ Picky Eater } & \multirow{2}{*}{ Bukan Picky Eater } \\
\hline Usia & $16(36,4 \%)$ & $28(63,6 \%)$ & \\
$12-24$ bulan & $22(64,7 \%)$ & $12(35,3 \%)$ & 0,493 \\
$25-36$ bulan & & $19(47,5 \%)$ & \\
Jenis Kelamin & $21(52,5 \%)$ & $21(55,3 \%)$ & \\
Laki-laki & $17(44,7 \%)$ & & \\
Perempuan & &
\end{tabular}

Note: ${ }^{*}$ p-value based on Chi-square test with alpha $5 \%$

\section{Karakteristik Ibu}

Karakteristik ibu salah satunya usia ibu dibagi menjadi 4 kategori yaitu remaja akhir, dewasa awal dan akhir serta lansia awal. Rentang usia responden yaitu 20 - 50 tahun. Rata-rata usia ibu yakni 29,1 tahun \pm 5,9. Berdasarkan Tabel 4, Menunjukkan sebagian besar usia ibu yang berada pada kelompok dewasa awal (26 - 35 tahun) sebesar $59,0 \%$. Hasil penelitian yang dilakukan di Australia menyatakan jika terdapat pengaruh usia ibu dengan praktik pemberian MP-ASI yang terlalu dini. Risiko 1,78 kali lebih besar pada ibu kelompok usia $\leq 35$ tahun dibandingkan dengan ibu yang berusia $>35$ tahun $^{10}$.

Data tingkat pendidikan diperoleh dari wawancara terkait dengan tingkat pendidikan formal yang terakhir ditempuh ibu. Pendidikan terendah ibu yakni tamat SD dan pendidikan tertinggi yakni sarjana. Rata-rata ibu memiliki tingkat pendidikan tamat SD. Berdasarkan Tabel 4, Sebagian besar tingkat pendidikan pada ibu pada kelompok kategori rendah yakni sebanyak $73,1 \%$. Penelitian yang dilakukan oleh Chatoor tahun 2009 didapatkan tingkat pendidikan ibu yang memiliki anak perilaku picky eater didapatkan pada kategori rendah $^{11}$.

Berdasarkan Tabel 4, menunjukkan sebagian besar responden memiliki status sebagai ibu tidak bekerja sebanyak $82,1 \%$. Ibu dengan status tidak bekerja cenderung memberikan MP-ASI yang terlalu dini kepada bayinya karena kurangnya informasi yang didapatkan dan lebih sering berada dirumah. Sumber informasi yang kurang didapatkan oleh ibu rumah tangga karena posyandu jarang didatangi dengan alasan kesibukan di rumah ${ }^{12}$.
Tabel 4. Distribusi Karakteristik Ibu

\begin{tabular}{lcc}
\hline \multicolumn{1}{c}{ Variabel } & \multicolumn{2}{c}{ Jumlah } \\
\cline { 2 - 3 } & $\mathbf{n}$ & $\%$ \\
\hline Usia & 22 & 28,2 \\
Remaja Akhir (17 - 25 tahun) & 46 & 59,0 \\
Dewasa Awal (26 - 35 tahun) & 8 & 10,3 \\
$\quad$ Dewasa Akhir (36 - 45 tahun) & 2 & 2,6 \\
$\quad$ Lansia Awal (46 - 55 tahun) & & \\
Tingkat Pendidikan & & \\
$\quad$ Rendah (Tidak sekolah, Tamat & 57 & 73,1 \\
$\quad$ SD dan SMP) & 19 & 24,4 \\
$\quad$ Menengah (Tamat SMA) & 2 & 2,6 \\
$\quad$ Tinggi (Diploma/Sarjana) & & \\
Pekerjaan Ibu & 14 & 17,9 \\
$\quad$ Bekerja & 64 & 82,1 \\
$\quad$ Tidak Bekerja & & \\
Pendapatan Keluarga & 19 & 24,4 \\
$\quad$ KI ( < Rp. 1.675.000 ) & & \\
KII (Rp. 1.675.000 - < Rp. & 26 & 33,3 \\
2.000.000 ) & & \\
KIII ( Rp. 2.000.000 - < Rp. & 16 & 20,5 \\
2.500.000) & 17 & 21,8 \\
$\quad$ KIV ( > Rp. 2.500.000) & &
\end{tabular}

Data pendapatan keluarga merupakan penghasilan yang didapatkan dari jumlah penghasilan dari setiap sumber pendapatan didalam keluarga tersebut setiap bulan. Pendapatan minimal keluarga sebesar Rp. 800.000 dan pendapatan tertinggi sebesar Rp. 6.000.000. Rata-rata pendapatan keluarga sebesar Rp. 2.178.205,13 $\pm 923.453,07$. Berdasarkan Tabel 4 . Pendapatan Keluarga menunjukkan pada kategori KII sebanyak 33,3\%. Keluarga dengan penghasilan pada kategori rendah akan mempengaruhi daya beli yang terbatas terkait bahan makanan sehat dengan harga 
terjangkau dibandingkan dengan keluarga yang memiliki penghasilan tinggi ${ }^{13}$.

Riwayat Pemberian Makanan Pendamping ASI (MP-ASI) Berdasarkan Tabel 5. Menunjukkan bahwa pemberian makanan pendamping ASI pada anak sebanyak $66,7 \%$ pada kategori tidak sesuai. Pemberian MP-ASI dengan kategori tidak sesuai berdasarkan waktu pemberian yang terlalu awal atau dini $(57,7 \%)$, tekstur terlalu encer maupun terlalu kasar $(55,1 \%)$, pemberian MP-ASI yang kurang bervariasi $(55,1 \%)$ dan jumlah yang diberikan terlalu sedikit (51,3\%). Saran MP-ASI diberikan dengan tepat adalah sejak usia 6 bulan, karena pada usia ini bayi sudah mulai mampu menggerakkan rahang keatas dan kebawah serta mampu menggenggam dengan telapak tangan ${ }^{14}$. Tujuan pemberian MP-ASI yang diberikan ketika usia 6 bulan maupun lebih yaitu agar anak tidak mengalami gangguan pencernaan maupun infeksi akibat virus atau bakteri ${ }^{15}$. Masih banyaknya pemberian MP-ASI yang dilakuakan oleh ibu terlalu awal atau dini karena $64 \%$ ibu berpendapat ASI tidak mencukupi kebutuhan bayi sehingga diberikan makanan tambahan seperti pisang, madu dan susu formula.

Pemberian MP-ASI merupakan awal pengenalan makanan selain ASI yang dapat mempengaruhi penerimaan makanan pada anak7. Preferensi makan anak yang berkembang secara genetik menggambarkan kecenderungan dan pengalaman seperti paparan secara berulang, suasana saat pemberian makan berlangsung, lingkungan psikologis dan sosial ${ }^{16}$. Hal ini sependapat dengan penelitian Lam tahun 2015 menyatakan bahwa paparan rasa makanan apabila dilakukan secara berulang akan meningkatkan food acceptance ${ }^{17}$.

Tabel 5. Distribusi Riwayat Pemberian Makanan Pendamping ASI (MP-ASI)

\begin{tabular}{lcc}
\hline Riwayat Pemberian Makanan & \multicolumn{2}{c}{ Jumlah } \\
\cline { 2 - 3 } \multicolumn{1}{c}{ Pendamping ASI (MP-ASI) } & $\mathbf{n}$ & $\mathbf{\%}$ \\
\hline Sesuai & 26 & 33,3 \\
Tidak Sesuai & 52 & 66,7 \\
\hline Total & 78 & 100,0 \\
\hline
\end{tabular}

\section{Persepsi Perilaku Picky Eater}

Berdasarkan Tabel 1, Ibu memiliki persepsi bahwa anak pada kategori bukan picky eater sebesar $51,3 \%$ dan mengalami perilaku picky eater sebesar $48,7 \%$. Hal ini menunjukkan hampir separuh dari ibu memiliki persepsi bahwa anak berperilaku picky eater. Prevalensi anak yang memiliki perilaku picky eater yang didapatkan lebih besar jika dibandingkan dengan hasil penelitian yang dilaksanakan Arifah tahun 2016 terhadap anak usia $12-36$ bulan sebesar $44,8 \%$ anak mengalami picky eater ${ }^{2}$. Hasil penelitian yang dilakukan Sumarni tahun 2015 anak usia toddler mengalami picky eater sebesar 40,6\% ${ }^{18}$. Hasil penelitian lain yang dilakukan Goh dan Jacob tahun 2012 menunjukkan 29,9\% anak mengalami perilaku picky eater ${ }^{19}$.

Berdasarkan hasil wawancara menunjukkan ibu memiliki persepsi bahwa bentuk perilaku makan anak yang sering dialami yaitu anak cenderung menolak sayur-sayuran atau buah sebesar $61 \%$ dan menolak daging sebesar 51\%. Anak lebih menyukai snack (makanan ringan) dibandingkan makanan utama sebesar $80 \%$, lebih menyukai makanan manis dan berlemak sebesar $74 \%$ dibandingkan dengan makanan sehat.

Tabel 1. Distribusi Persepsi Perilaku Picky Eater

\begin{tabular}{lcc}
\hline \multirow{2}{*}{ Persepsi Perilaku Picky Eater } & \multicolumn{2}{c}{ Jumlah } \\
\cline { 2 - 3 } & $\mathbf{n}$ & $\%$ \\
\hline Picky Eater & 38 & 48,7 \\
Bukan Picky Eater & 40 & 51,3 \\
\hline Total & 78 & 100,0 \\
\hline
\end{tabular}

Perilaku picky eater salah satu fase yang sering terjadi pada masa tumbuh kembang anak yang tidak akan selalu menimbulkan permasalahan kesehatan maupun sosial. Picky eater yang terlalu ekstrem dan berlangsung dalam jangka waktu yang lama apabila tidak ditangani dengan tepat dapat berakibat buruk pada anak, seperti gagal tumbuh, penyakit kronis dan kematian. Rendahnya asupan mikronutrien dan makronutrien sering terjadi pada anak yang memiliki perilaku picky eater dan dapat mempengaruhi pertumbuhan fisik anak dapat ditandai dengan berat badan rendah atau kurangnya tinggi badan dan dapat mempengaruhi pertumbuhan kognitif ${ }^{4}$.

\section{Hubungan Riwayat Pemberian Makanan Pendamping ASI (MP-ASI) dengan Persepsi Perilaku Picky Eater}

Berdasarkan Tabel 6, Bahwa menunjukkan hubungan antara riwayat pemberian MP-ASI dengan persepsi perilaku picky eater menunjukkan bahwa kedua variabel mempunyai hubungan yang saling berkaitan. Sejalan dengan hasil penelitian Purnamasari tahun 2018 dilakukan pada anak usia pra sekolah adanya hubungan yang signifikan antara riwayat pemberian MP-ASI dengan perilaku picky eater ${ }^{20}$.

Anak yang memiliki perilaku picky eater berkaitan dengan kurangnya anak dipaparkan atau dikenalkan makanan yang bervariasi oleh orang tua ${ }^{9}$. Tahap pengenalan makanan dimulai ketika pemberian MP-ASI dan dilakukan pemaparan secara berulang yang dapat berpengaruh terhadap penerimaan makan anak hingga dewasa ${ }^{21}$. Penerimaan rasa pada anak akan lebih mudah apabila makanan sudah dikenal ${ }^{22}$. Waktu pemberian MP-ASI yang lebih dini maupun terlambat dapat menyebabkan anak sulit mengenal makanan baru sehingga terbatasnya variasi makanan ${ }^{5}$.

Tabel 6. Hubungan Riwayat Pemberian Makanan Pendamping ASI (MP-ASI) dengan Persepsi Perilaku Picky Eater

\begin{tabular}{llll}
\hline \multicolumn{1}{c}{$\begin{array}{c}\text { Riwayat Pemberian Makanan } \\
\text { Pendamping ASI (MP-ASI) }\end{array}$} & \multicolumn{1}{c}{ Persepsi Perilaku Picky Eater } & p-value \\
\cline { 2 - 3 } Sesuai & \multicolumn{1}{c}{ Picky Eater } & \multicolumn{1}{c}{ Bukan Picky Eater } & $<0.001$ \\
Tidak Sesuai & $36(6,7 \%)$ & $24(92,3 \%)$ & \\
\hline
\end{tabular}

Note: p-value based on Chi-square test with alpha $5 \%$

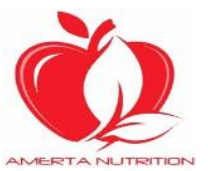


Namun, MP-ASI yang diberikan tidak sesuai akan mempengaruhi perilaku makan pada anak.

\section{KESIMPULAN}

Hasil penelitian menunjukkan sebagian besar riwayat pemberian MP-ASI pada anak kategori tidak sesuai berdasarkan waktu pemberian yang terlalu dini, tekstur terlalu encer maupun terlalu kasar, pemberian MP-ASI yang kurang bervariasi dan jumlah yang diberikan terlalu sedikit. Terdapat hubungan yang signifikan antara riwayat pemberian MP-ASI dengan persepsi perilaku picky eater pada anak. Anak dengan riwayat pemberian MP-ASI yang tidak sesuai sebagian besar cenderung mengalami perilaku Picky Eater.

\section{ACKNOWLEDGEMENT}

Ucapan terimakasih penulis berikan kepada Badan Kesatuan Bangsa, Politik dan Perlindungan Masyarakat Provinsi Kota Surabaya, Dinas Kesehatan Kota Surabaya dan Puskesmas Sidotopo telah memberikan izin dilaksanakannya penelitian ini dan membantu kelancaran selama proses penelitian, kepada dosen pembimbing atas arahan, pengajaran sera bimbingan yang telah diberikan.

\section{REFERENSI}

1. Li, Z., van der Horst, K., Edelson-Fries, L.R., and others. Perceptions of food intake and weight status among parents of picky eating infants and toddlers in China: A cross-sectional study. Appetite 108, 456-463 (2017).

2. Arifah, U., Endang, D. L. \& Ayusari, A. A. Hubungan Pemberian ASI Eksklusif dengan Picky Eater pada Anak Usia 1-3 Tahun di Puskesmas Kratonan Surakarta. Nexus Kedokt. Komunitas 5, 23-30 (2016).

3. Yulis, Z. E. \& Hamid, M. A. Analisis Pilih Pilih Makan Pada Anak Usia 1 Sampai 3 Tahun Di Desa Suci Kabupaten Jember. J. Pengabdi. Masy. Ipteks 2, 82-89 (2016).

4. Kusumawardani, N. Determinan "Picky Eater" (Pilih-Pilih Makanan) pada Anak Usia 1-3 Tahun (Studi di Wilayah Kerja Puskesmas Jabon Sidoarjo) [Thesis]. (Universitas Airlangga, 2013). doi:10.1002/14651858.CD004439.pub2.De

5. Shim, J. E., Kim, J. \& Mathai, R. A. Associations of Infant Feeding Practices and Picky Eating Behaviors of Preschool Children. J. Am. Diet. Assoc. 111, 1363-1368 (2011).

6. Maseko, M. \& E, O. E. Child Malnutrition And Mortality In Swizeland Situation Analysis Of The Immedate, Underlying And Basic Causes. African J. Food, Agric. Nutr. Dev. 12, (2012).

7. Utami, F. B. Picky Eater Pada Anak Kota: Studi Kasus Anak Usia 3-4 Tahun. J. Sosioreligi 14, 7986 (2016).
8. Adriani, M. \& Wirjatmadi, B. Peranan Gizi dalam Siklus Kehidupan. (Kencana, 2012).

9. Chao, H. C. \& Chang, H. L. Picky Eating Behaviors Linked to Inappropriate Caregiver-Child Interaction, Caregiver Intervention, and Impaired General Development in Children. Pediatr. Neonatol. 58, 22-28 (2017).

10. Scott, J. A., Binns, C. W., Graham, K. I. \& Oddy, W. H. Predictors of the early introduction of solid foods in infants: Results of a cohort study. BMC Pediatr. 9, 1-9 (2009).

11. Chatoor, I. Sensory Food Aversions in Infant and Toddler. Zero To Tree 44-50 (2009).

12. Rani, D. \& Supatmi. Hubungan Pemberian Jenis Makanan Penamping ASI Dini dengan Motilitas Usus pada Bayi Usia 0-6 Bulan. Sun 2, 24-30 (2015).

13. Purnama, N. L. A., Lely, L. \& Madarina, J. Perilaku orang tua dalam pemberian makan dan status gizi anak usia 2-5 tahun. J. Gizi Klin. Indones. 11, 97-104 (2015).

14. Gulo, M. J. \& Nurmiyati, T. Hubungan Pemberian MP-ASI dengan Status Gizi Bayi Usia 6-24 Bulan Di Puskesmas Curug Kabupaten Tangerang. J. Bina Cendekia Kebidanan 1, 8-14 (2015).

15. Hikmah, N. Riwayat pemberian asi, susu formula, dan $\mathrm{mp}$-asi pada anak balita dengan risiko gizi lebih di Kecamatan Majalengka [Skripsi]. (Institut Pertanian Bogor, 2016).

16. Xue, Y. et al. Growth and development in Chinese pre-schoolers with picky eating behaviour: A cross-sectional study. PLoS One 10, 1-16 (2015).

17. Lam, J. Picky eating in children. Front. Pediatr. 2, 1-3 (2015).

18. Sumarni. Hubungan picky eater dengan status gizi pada anak usia toddler. J. Kesehat. Al- Irsyad 8, 26-33 (2015).

19. Goh, D. Y. T. \& Jacob, A. Perception of picky eating among children in Singapore and its impact on caregivers: a questionnaire survey. Asia Pac. Fam. Med. 11, 1-8 (2012).

20. Purnamasari, A. . Hubungan riwayat pemberian makanan pendamping asi (mp-asi) dengan perilaku picky eater dan status gizi pada anak usia pra sekolah di Paud Anggrek 1 Siwalankerto Surabaya [Skripsi]. (Universitas Airlangga, 2018).

21. Nicklaus, S. Children's acceptance of new foods at weaning. Role of practices of weaning and of food sensory properties. Appetite 57, 812-815 (2011).

22. Remy, E., Issanchou, S., Chabanet, C. \& Nicklaus, S. Repeated Exposure of Infants at Complementary Feeding to a Vegetable Purée Increases Acceptance as Effectively as FlavorFlavor Learning and More Effectively Than Flavor-Nutrient Learning. J. Nutr. 143, 11941200 (2013). 